agricultural regions.126 In those areas, however, the movement may still continue to have considerable significance, particularly if forthcoming state and federal efforts to legislate in the interest of farm tenants and share croppers utilize the techniques and the experience of the homestead laws. ${ }^{127}$

\title{
POSTPONEMENT OF MATURITY DATES UNDER TRUST INDENTURES
}

THE RECENT experience of the United States Radiator Corporation is typical of one of the many situations in which it becomes expedient for a debtor corporation to postpone the maturity date of its outstanding obligations. The Radiator Corporation does a seașonal business requiring the manufacture of products in advance of the months of heavy demand. Not long ago it attempted to finance this pre-season production by bank loans, but in order to obtain the necessary credit, it found it necessary to postpone the maturity date of certain of its outstanding debentures which fall due on February 1, 1938. It therefore proposed a plan whereby the outstanding debentures are to be exchanged for new bonds, payable on August 1,1946.1 While the plan will probably be accepted by a majority of the debenture holders, non-assenters will be able to demand payment on the maturity date with a corresponding drain on the company's finances, unless they are prevented from suing by the terms of the indenture.?

This situation prompts an inquiry as to when a dissenting bondholder ${ }^{3}$ may be forced, either at the hands of the legislature or by a majority of the

126. It is significant that in the United States most of the recent activity in this field of the law has taken place in the southern and western states. See Vance, risro note 2 , at 442 .

127. For evidence of concern as to the increase in farm tenancy, see N.Y. Times, Sept. 24, 1936, p. 24, col. 1; id. Nov. 18, 1936, p. 16, col. 2; id. Dec 17, 1936, p. 9, col. 2. It has been suggested that legislation designed to correct this condition should include provisions to protect the farmer's property from creditors. See N. Y. Timas, Feb. 12, 1937, p. 1, col. 1; id. Feb. 13, 1937, p. 1, col. 1.

1. See United States Radiator Corporation, Plan of Reorganization and Deposit Agreement (June 1, 1936) 2-3. Similar problems arise when maturity falls in a year of unfavorable interest rates or business conditions. See circular issued by the Grent Northern Railway Company (dated Jan. 1, 1937), providing for the issuance of Gereral Mortgage 3 z $4 \%$ Bonds, Series I.

2. Some indentures provide that only the trustee may bring suit and that he cannot be forced to do so save upon the demand of a certain percentage of the bondholders. It seems that such provisions are binding upon dissenters. Allan v. Moline Plow Co., 14 F. (2d) 912 (C. C. A. 8th, 1926) ; cf. Gellert v. Baldwin Locomotive Works, 3 F. Supp. 812 (E. D. Pa. 1933).

3. Unless otherwise specified, the discussion herein relating to bonds will be equally applicable to debentures. 
bondholders, to accede to a postponement of the maturity date in his bond. Such an inquiry should prove particularly significant in view of the increasing popularity of a new type of trust indenture, which expressly provides for its release or amendment by the consent of less than all of the bondholders. ${ }^{4}$ There appears to be little case law on the subject, but some basis for prophecy may be found in the related body of law concerning corporate charter amendment, where a majority of stockholders is usually given wide powers to alter the rights and preferences attaching to the individual investor's shares. ${ }^{5}$

It seems clear that as to bonds already in existence, neither the legislature nor less than all of the bondholders can postpone retrospectively the obligation of the issuer to pay the principal at the time specified in the indenture. State laws altering the maturity date of existing bonds have been held unconstitutional on the ground that they impaired the contract between the bondholder and the corporation, ${ }^{6}$ and the same objection would probably vitiate a law which purported to grant this power to a majority of bondholders. ${ }^{7}$ The police power appears to be the sole basis for sustaining such legislation, ${ }^{8}$ but it could be successfully invoked only by convincing the court that an emergency existed for which the statute was a reasonable remedy. ${ }^{0}$ This might well prove impossible, for the situations would be few in which a large proportion of corporations would be in sufficiently bad financial straits to warrant such legislation. ${ }^{10}$ The ordinary requirements of contract law

4. Securttes and Exchange Commission, Report on the Study and Investigation of the Work, Activities, Personnel and Functions of Protective and Reorganization Committees, Part III (1936) 226.

5. Curran, Minority Stockholders and the Amendment of Corporate Charters (1934) 32 Mrch. L. Rev. 743. Of course this power depends upon the actual provisions of the charter and the local corporation laws; Comment (1937) 46 Y ALE L. J. 985.

6. Chicago \& I. R. R. v. Pyne, 30 Fed. 86 (C. C.S.D. N. Y. 1887) (attempted acceleration of maturity date); Randolph v. Middleton, 26 N. J. Eq. 543 (1875); 2 Jones, Bonds ANd Bond Securities (4th ed. 1935) §755.

7. In the stockholder cases, it is usually held that the power of the state to amend corporate charters includes the power to offer amendments to a majority. See Dodd, Dissenting Stockholders and Amendments to Corporate Charters (1927) 75 U. of PA. L. REv. 585, 723, and cases cited at 725, n. 69. Contra: Dow v. Northern R. R., 67 N. H. 1,36 Atl. 510 (1887); see 2 Cook, Corporations (8th ed. 1923) $\$ 501$.

8. Private contracts are subject to the exercise of the state's police power. Marcus Brown Co. v. Feldman, 256 U. S. 170 (1921); Levy Leasing Co. v. Siegel, 258 U. S. 242 (1922); cf. Norman v. Baltimore \& O. R. R., 294 U. S. 240 (1935).

9. This is true of legislation affecting the rights of stockholders. Treigle v. Acme Homestead Ass'n, 297 U. S. 189 (1936). Equity courts have at times permitted departures from the terms of trust indentures where strict adherence to them was rendered impossible by the existence of an emergency. N. J. Nat. Bank \& Trust Co. v. Lincoln Mortgage \& Title Guaranty Co., 105 N. J. Eq. 557, 148 Atl. 713 (1930).

10. Recourse to the police power might prove more successful if the legislation involved were confined solely to quasi-public corporations and municipalities. Rocker v. Cardinal Building \& Loan Ass'n, 13 N. J. Misc. 397, 179 Atl. 667 (Sup. Ct. 1935). But 
would undoubtedly defeat the efforts of a majority of bondholders to alter on their own initiative the maturity date of all the bonds. ${ }^{11}$ It is true that although a charter is said to be a contract between the corporation and all the stockholders, ${ }^{12}$ a majority of them may amend it without having reserved that right, so long as the state consents and the changes can be classified as incidental to and in furtherance of the original purposes of the corporation. ${ }^{13}$ But it has been held that this rule does not permit majority stockholders to alter redemption dates of preferred stock, such changes being regarded as fundamental rather than incidental, and a deprivation of dissenting stockholders' vested rights. ${ }^{14}$ Furthermore, the holdings allowing incidental changes in charters may be attributed to a judicial policy of facilitating a measure of flexibility in corporate management, ${ }^{10}$ and the same interest might not be regarded as applicable to the postponement of maturity dates of obligations. One of the primary functions of a charter is to describe managerial activity, and the stockholders whose contract rights it sets forth are directly concerned with corporate control; the contract between the corporation and the bondholders, on the other hand, is usually designed to govern the conduct of corporate affairs only in a limited area, and the bondholders whose rights it sets out are ordinarily regarded as having only an indirect interest in and control of corporate management. Hence, while the alteration of the latter contract might assist the corporation's financial policy, it seems less appropriate to justify such action as being in the interests of flexible management than in the case of charter amendment.

If less than all the bondholders attempt to postpone the maturity date of bonds under a power of amendment which was provided for by statute or in an indenture before the bonds in question were issued, different considertions become relevant. ${ }^{18}$ The initial problem would be to decide whether the

cf. Baker v. Tulsa Bldg. \& Loan Ass'n, Okla. Sup. Ct, October 6, 1936. In the care of municipalities, such provisions might well prove the most effective means of reosganization, since it has been held that municipalities cannot seek relief under the Banlsruptcy Act. Ashton v. Cameron County Water Improvement Dist., 293 U. S. 513 (1936).

11. Missouri, K. \& T. Ry. v. Union Trust Co., 156 N. Y. 592, 51 N. E. 309 (1893) (attempted acceleration of maturity date); Kaleta v. Archer Coal and Material Co., 5 N. E. (2d) 879 (IIl. App. 1936).

12. 7 Fletcher, Cyclopedia of the Law of Prtvate Corforatrons (rev. ed. 1931) § 3657.

13. Perkins v. Coffin, 84 Conn. 275, 79 Atl. 1070 (1911); Mower v. Staples, 32 Minn. 284, 20 N. W. 225 (1884); Woodfork v. Union Bank, 43 Tenn. 483 (1865).

Since a charter is considered a grant of authority by the state, it cannot be amended without the state's consent. See Dodd, supra note 7, at 586.

14. Johnson v. Tribune-Herald Co., 155 Ga. 204, 116 S. E. 810 (1923); Star Publishing Co. v. Ball, 192 Ind. 158, 134 N. E. 285 (1922).

15. Curran, supra note 5 , at 745 .

16. It is clear that a provision in an indenture granting to a majority of the bondholders certain powers other than that of amendment may be binding on all the bond- 
amendment provision could be construed as authorizing the postponement. It seems probable that an express provision for the postponement of maturity dates would be necessary. In the stockholder cases, it has usually been held that a general power to amend, reserved either by the state ${ }^{17}$ or in the corporate charter, ${ }^{18}$ does not authorize such amendments as would constitute a radical departure from the original objects of the corporation, or which would deprive dissenting stockholders of "vested" rights. There is no unanimity in the decisions as to what is meant by these terms, but in general, the courts are apparently slow to find fatal objections in amendments which may be said to relate to the enterprise as a whole, while they are stricter in determining the validity of those which affect directly the rights of the individual stockholder, and with respect to which it is easier to raise the claim of vested rights. ${ }^{19}$ While it is impossible to draw a line between these categories, it appears that the right to redeem preferred stock is a "vested" right and cannot be postponed under a general power of amendment, since it is of great concern to the individual and is, as a rule, a minor factor in the management of the corporation. ${ }^{20}$ This conclusion seems the more likely in that similar rights of the individual stocklolder, like the right to have a sinking fund maintained, ${ }^{21}$ or the right to accrued cumulative dividends, ${ }^{22}$ have also been considered vested.

But even where the amendment provision could be construed as authorizing a postponement of maturity dates, an investor would not be held to have subjected himself to the will of the majority unless he had some notice of the provision when he purchased his bonds. Actual notice would clearly be sufficient, ${ }^{23}$ and if the power of amendment were found in a statute no further notice to the bondholder would be necessary. ${ }^{24}$ But where it was

holders. Sage v. Central R. R., 99 U. S. 334 (1878) (power to authorize trustee to purchase at foreclosure sale).

17. Allen v. White, 103 Neb. 256, 171 N. W. 52 (1919) ; Pronik v. Spirits Distributing Co., 58 N. J. Eq. 97, 42 Atl. 586 (1899); Huber v. Martin, 127 Wis. 412, 105 N. W. 1031 (1906).

18. Wright v. Knights of Maccabees, 196 N. Y. 391, 89 N. E. 1078 (1909); see Berle, Studies in the Law of Corporation Finance (1928) 85.

19. See Dodd, Amendment of Corporate Articles under the New Ohio General Corporation Act (1930) 4 U. of CIN. L. Rev. 129, 160; Comment (1929) 77 U. of PA. L. REv. 256, 259-260.

20. Sutton v. Globe Knitting Works, 267 N. W. 815 (Mich. 1936); see Jones, Redeemable Corporate Securities (1932) 5 So. CAlif. L. REv. 83, at 89. The Sulton case is particularly significant since the preferred stock was in effect a debt of the corporation, redemption being mandatory rather than optional.

21. Yoakam v. Providence Biltmore Hotel Co., 34 F. (2d) 533 (D. R. I. 1929).

22. Keller v. Wilson, Del. Sup. Ct., Nov. 10, 1936.

23. Actual notice is sufficient in the stockholder cases. Baldwin v. Miller \& Lux, 152 Cal. 454, 92 Pac. 1030 (1907) ; Maddock v. Vorclone Corporation, 17 Del. Ch. 39, 147 Atl. 255 (1929); see General Investment Co. v. American Hide \& Leather Co., 97 N. J. Eq. 214, 224, 127 Atl. 529, 533 (1925); Jones, loc. cit. supra note 20.

24. Cf. Boyette v. Preston Motors Corporation, 206 Ala. 240, 89 So. 746 (1921). 
contained in the indenture, some mention of it might have to be made in the bond.25 An express reference to the actual provision would undoubtedly fulfill all requirements, ${ }^{26}$ but whether this would be true of a general reference to the indenture as a whole would apparently depend upon the particular jurisdiction in question. ${ }^{27}$

Aside from the questions of construction and notice, there remains the possibility that a disgruntled bondholder might seek to enjoin or set aside a postponement of a maturity date on the ground that it vas either fraudulent or unduly. oppressive. ${ }^{28}$ It has been held in the stockholder cases in-

25. See Stetson, Preparation of Corporate Bonds, Mlorlgages, Collateral Trusts and Debenture Indentures in 1 Soure Legal Phases of Corporate Fnancting, RozanmizaTION, AND Regulation (1917) 16. A stockholder is charged with notice of the charter and the corporate by-laws, whether or not they are referred to in his stod: certificate. Richardson v. Devine, 193 Mass. 336, 79 N. E. 771 (1907); Nicholson จ. Frantilin Brewing Co.. 82 Ohio St. 94, 91 N. E. 991 (1910). But there are grounds for a different rule as to indentures. Indentures are merely private contracts, while a corporate charter, and the by-laws in that they are formed under the charter, are created pursuant to statute of which the stockholder is deemed to have notice. Furthermore, charter provisions must be publicly recorded, whereas normally in the care of trust indentures, the only notice from public recordation would be that provided if the loan were secured by a recorded mortgage.

26. Cf. Mitchell v. Madison Avenue Offices, 147 Misc. 149, 263 N. Y. Supp. 442 (City Ct. 1933) ; 7 FLETCHER, op. cit. supra note 12, $\$ 3157$.

27. Cf. Home Mortgage Co. v. Ramsey, 49 F. (2d) 738, 740 (C. C. A. 4th, 1931) ("reference to which [indenture] is hereby made for a description ... of the rights ... of the holders of the bonds . . ." held sufficient to bind bondholders to terms of indenture); Harvey v. Illinois Power \& Light Corp., 3 F. Supp. 4S9, 490 (E D. III. 1933) (similar reference held sufficient); Cunningham v. Pressed Steel Car Co., 238 App. Div. 624. 625, 265 N. Y. Supp. 256, 258 (1st Dep't 1933) ("to which indenture reference is hereby made for a statement of the rights of the holders of caid bonds," held insufficient to bind bondholder); Comments (1935) 33 Mricr. I. REv. $604,1082$.

28. The protection which equity affords a minority stockholder against the actions of an uncontrolled majority is well evidenced by the cases involving statutory merger and consolidation. Allied Chemical \& Dye Corp. v. Steel \& Tube Co., 14 Del. $\mathrm{Cl}_{\text {. }} 1$, 120 Atl. 486 (1923); Homer v. Crown Cork \& Seal Co., 155 ard. 66, 141 Atl. 425 (1928) ; Colby v. Equitable Trust Co., 124 App. Div. 262, 108 N. Y. Supp. 978 (1st Dep't 1908); see Comment (1936) 45 Y YLE I J. 105, at 117. This Comment points out (at page 119) that it is not alway's clear whether unfairness alone, in the absence of fraud, is a sufficient basis for court action.

Language in Sage v. Central R. R. Co., 99 U. S. 334, 339, 341 (1878), indicates a similar attitude as to the power of the majority under an indenture to authorize the trustee to purchase at the foreclosure sale: "What that agreement [the indenture provision] was, what purpose it was intended to subserve, against what mischief it ras proposed to guard. and by what mode it was stipulated the object intended should be accomplished, it is very important to consider. . . . While it [the provision] prevented a small minority of the bondholders from forcing unreasonable and inequitable concessions from the majority, it did not empower that majority to crush out the rights of the minority, or subject them to any disadvantage." For a similar viewpoint, see Ikelheimer v. Consolidated Tobacco Co., 59 Atl. 363 (N. J. Ch. 1904). 
volving charter amendments that a majority occupies a fiduciary relation to the minority, ${ }^{29}$ and hence the courts, although unwilling to supervise the managerial soundness of corporate policy, have granted equitable relief where it was evident that the proposed amendment was made in bad faith, ${ }^{30}$ or was unfair, as where it would unduly prefer one class of investors to another, ${ }^{31}$ or unnecessarily destroy the special rights and privileges inhering in a particular type of security. ${ }^{32}$ In the case of alteration of maturity dates, the charge of unfairness might frequently be available, for trust mortgages often provide for the issuance of several series of bonds, and therefore amendments with respect to one series might injure its security in any one of several ways: by a discrimination between bond series of nominally equal rank, or a postponement of access to the mortgaged property before its waste or dissipation. It seems, moreover, that the action of the majority could be attacked as being undertaken in bad faith, just as in the stockholder cases, on the ground of improper motives or conflicting interests, as where, for instance, the proposed amendment would prove of financial benefit to its proponents in some other respect than in their capacity as bondholders. ${ }^{33}$

Attempts to postpone the maturity date of bonds, as distinguished from debentures, might involve further problems as to whether the lien securing the bonds could be extended without infringing the rights of junior lienors. In the absence of express provision in either mortgage, it is generally held that a first mortgage may be extended despite the objections of second mortgagees, since an extension is regarded as one of the privileges of prior en-

29. Southern Pacific Co. v. Bogert, 250 U. S. 483, 488 (1919). Similar requirements of good faith are imposed upon a majority of bondholders. Hackettstown Nat. Bank v. Yuengling Brewing Co., 74 Fed. 110 (C. C. A. 2d, 1896).

30. MacArthur v. Port of Havana Docks Co., 247 Fed. 984 (D. Me. 1917) (sale of assets); General Investment Co. v. American Hide \& Leather Co., 97 N. J. Eq. 214, 127 Atl. 529 (1925) (conflicting interests).

31. Eagleson v. Pacific Timber Co., 270 Fed. 1008 (D. Del. 1920); see MacFarlane v. North American Cement Corp., 16 Del. Ch. 172, 178, 157 Atl. 396, 398 (1928).

32. Boyd v. N. Y., \& H. R. R., 220 Fed. 174 (S. D. N. Y. 1915) (threatened loss of peculiar value of security through proposed merger); Outwater v. Public Service Corp., 103 N. J. Eq. 461, 143 Atl. 729 (Ch. 1928), aff'd, 104 N. J. Eq. 490, 146 Atl. 916 (1929) (preferred stock made redeemable after three years at will of corporation).

33. Such a situation might arise where the amendment was in aid of a sale of securities or assets to a corporation in which either the trustee or some of the concurring bondholders were financially interested. Cf. General Investment Co. v. American Hide \& Leather Co., 97 N. J. Eq. 214, 127 Atl. 529 (1925).

Since it is generally held that a majority occupies a fiduciary relation to the minority [see note 29, stpra], it might be maintained that an arbitrary exercise of their power would constitute a fraud upon it and would be void as a result. Such a doctrine applies in cases where the holder of a limited power of appointment (who is termed a trustee of the forum) seeks to deviate from the donor's directions by an agreement with the appointee. In re Carroll's Estate, 247 App. Div. 11, 286 N. Y. Supp. 307 (1st Dep't 1936), (1936) 46 YaLe L. J. 344. 
cumbrancers to which subsequent lienors are subject. ${ }^{34}$ But where it is attempted to extend the first mortgage to secure bonds bearing a higher rate of interest than the old ones, the lien is probably ineffective to secure the interest obligation above the old rate ${ }^{35}$ unless, perhaps, the amount of the principal obligation is correspondingly reduced so that the total prior charge against the property is no greater than under the original mortgage. ${ }^{20}$ Moreover, if the second mortgage indenture contains an express covenant by the mortgagor that the discharge of prior liens will not be postponed, the extension of the first mortgage would certainly constitute a breach of that covenant making available all the remedies afforded by the indenture, and might conceivably be ineffective to continue the first mortgage lien. ${ }^{37}$

The chief advantage of granting power to a majority of bondholders to postpone maturity dates would be to facilitate a voluntary reorganization of the corporation or to postpone insolvency proceedings in court. A voluntary reorganization is often desirable in view of the expense, delay and unfavorable publicity attending court proceedings, ${ }^{88}$ but is a virtual impossibility in a bond issue of any size where the unanimous consent of the bondholders is necessary, since there are always those who dissent as a matter of opinion or as a step in coercing the majority to buy out their claims. 50 This diffculty is the motivating cause for the provisions now being inserted in indentures, which by contract provide the machinery for reorganization vith the consent of less than all of the bondholders. ${ }^{10}$ Thus far, however, there has been little attempt to provide for postponement of maturity dates by

34. Commonwealth Life Ins. Co. v. Louisville Ry., 234 Ky. 802, 29 S. W. (2d) 552 (1930).

35. See Barbano v. Central-Hudson Steamboast Co., 47 F. (2d) 160, 162 (C. C. A. 2d, 1931); 1 Jones, Moztgages (8th ed. 1928) §444.

36. Where part of the first mortgage debt has been paid, the interest rate on thoce bonds that remain may be increased so long as no greater encumbrance is placed wron the land than that which existed when all of the bonds were still in full force Campbell v. Texas \& N. O. R. R., 4 Fed. Cas. No. 2,369, at 1188 (C. C.E. D. Tex 1872).

37. Cf. Commonwealth Life Ins. Co. v. Louisville Ry., $234 \mathrm{Ky} .802,810,29 \mathrm{~S}$. W. (2d) 552, 556 (1930). For an indenture containing such a provision, see Chicago, Roci: Island and Pacific Railway to Central Trust Co. of New York, Trustee (Appendis, dated April 1, 1904) 159.

38. See Sectirities axd Exchange Commusission Report, Pait VI, op. cit. sispro note 4 , at 145 .

39. Voluntary reorganizations are in rare instances successful. That of the Boston and Maine Railroad in 1925 is a notable example.

A corporation may at times avoid a court reorganization by persuading a sufficiently large proportion of its creditors to enter into a composition agreement. Mraturity dates have at times been postponed by such means. Globe Wernicke Co. v. Siegd Alyers School of Mrusic, 209 Ill. App. 529 (1918); Meyer Mffg. Co. v. Iowa Valley Sugar Co., 199 Iowa 797, 202 N. W. 570 (1925).

40. Securtties and Exchange Cosmission Report, Paist VI, op. cit. sispro note 4, at 143-145. 
the exercise of such powers. ${ }^{41}$ Indeed, the great majority of those indentures which contain provisions for amendment expressly exclude any action impairing the obligation of the issuer to pay principal or interest in the manner specified in the bond, ${ }^{42}$ the purpose apparently being to provide for voluntary reorganization by other means, as for example, by altering the relative preferences of the bonds, authorizing a sale of the corporation's assets, or releasing its property from the indenture and mortgaging it to others in return for new loans. ${ }^{43}$ It is somewhat difficult to understand why maturity dates are expressly made sacrosanct, for the power to postpone them would undoubtedly prove of considerable value, and to restrict the power of the majority in this respect would seem hardly consistent with the authority given it to alter matters of apparently greater importance, such as those previously suggested. But the ultimate desirability of inserting provisions for the alteration of maturity dates does not depend alone upon whether this particular form of amendment is more or less advantageous than others. The whole practice of authorizing a majority to make amendments should be considered with a view to weighing the benefits of convenience and efficiency to be gained therefrom against the possibilities of abuse in reorganizations conducted without court supervision. ${ }^{44}$

41. This appears to have been done in the indenture under consideration in Campbell River Timber Co. v. Vierhus, 86 F. (2d) 673 (C. C. A. 9th, 1936) (extension of maturity dates by supplemental indenture held "renewal" of bonds subjecting them to stamp tax).

42. Securities and Exchange Commission Report, Part VI, op. cil. sitpra note 4, at 137. For a collection of indentures permitting amendments, see id. at 135 . The indenture, Chicago Builders' Co. to National Builders Bank of Chicago, Trustec (dated April 1, 1936) 76, would apparently permit alteration of interest and of maturity dates.

43. See United States Steel Corporation to United States Trust Company of New York (dated April 1, 1903) 56; Montana-Dakota Power Company to the Minnesota Loan and Trust Company and Charles V. Smith (dated April 1, 1926) 79; and indentures cited note 42 , supra.

44. Securities and Exchange Commission Report, Part VI, op. cit. supra note 4 , at 150 . When the reorganization calls for the exchange of securities, court supervision may still be found desirable as a means of gaining exemption from the requirements of the Securities Act under Section 3(a) (10) of that Act. See Comment (1936) 45 YALE L. J. 1050. 